\title{
Oral Propranolol for Circumscribed Choroidal Hemangioma
}

\author{
Empar Sanz-Marco ${ }^{a}$ Roberto Gallego a, b \\ Manuel Diaz-Llopis ${ }^{\mathrm{a}-\mathrm{c}}$ \\ aDepartment of Ophthalmology, New University and Polytechnic Hospital La Fe, \\ ${ }^{b}$ Biomedical Research Center for Rare Diseases Network (CIBERER), and 'Faculty of \\ Medicine, University of Valencia, Valencia, Spain
}

\section{Key Words}

Circumscribed choroidal hemangioma $\cdot$ Propanolol $\cdot \beta$-Blocker

\begin{abstract}
Introduction: Several therapeutic approaches have been developed to treat choroidal hemangioma. However, all these therapies are associated with a potential risk of damaging the overlying retina.

Case Report: We report a case of circumscribed choroidal hemangioma $(\mathrm{CCH})$ in a 59year-old man refractory to laser treatment. Visual acuity was 20/200 and a serous macular detachment was present. The $\mathrm{CCH}$ was treated with oral propanolol, whereupon visual acuity improved to $20 / 20$ and the macular detachment resolved without systemic or local adverse effects.

Discussion: Propanolol is a $\beta$-blocker commonly used in cardiology that may induce endothelium vasoconstriction and inhibit endothelial proliferation. It has been shown to be effective in infantile facial hemangiomas, and proved safe and effective for the $\mathrm{CCH}$ in our patient. Further studies are needed to confirm our observation.
\end{abstract}

\section{Introduction}

There are two types of choroidal hemangiomas: circumscribed choroidal hemangioma $(\mathrm{CCH})$ and diffuse choroidal hemangioma $(\mathrm{DCH})$.

$\mathrm{CCH}$ is a rare benign, commonly asymptomatic vascular tumor which is usually diagnosed in adulthood when it becomes symptomatic with visual acuity decline, visual field defect or metamorphopsia due to exudative retinal detachment. CCH appears as an orange choroidal mass with indistinct borders, usually within the macular area [1]. 
In contrast, $\mathrm{DCH}$ is usually evident at birth and typically occurs as part of neurooculocutaneous hemangiomatosis (Sturge-Weber syndrome), but it frequently does not become manifest until adolescence. DCH appears as a diffuse orange choroidal thickening. Despite this, focal regions of excessively thickened choroid may simulate $\mathrm{CCH}[2]$.

Choice of treatment for choroidal hemangiomas is based on tumor location, presence of subretinal fluid, extent of symptoms, and potential for visual recovery. Periodic observation alone is an optimal choice for asymptomatic cases without subretinal fluid. When vision loss occurs, different treatment options include: photodynamic therapy (PDT), transpupillary thermotherapy, vascular endothelial growth factor (VEGF), laser photocoagulation, episcleral plaque radiotherapy, cryotherapy, external beam radiotherapy, and stereotactic radiotherapy [2]. Despite their efficacy, inducing tumor atrophy, all these treatments are associated with the potential risk of damaging the overlying retina.

A new treatment has emerged for infantile hemangiomas: systemic propanolol [3]. Propanolol is a nonselective $\beta$-adrenergic receptor blocker commonly used for cardiologic indications. It seems to be safe and effective in orbital, eyelid and facial hemangiomas in children.

\section{Case Report}

A 59-year-old man with arterial hypertension $(150 / 95 \mathrm{~mm} \mathrm{Hg}$ ) was seen in our department because of visual acuity (VA) decline and metamorphopsia of his left eye (OS) for 5 weeks. VA was 20/20 for his right eye and 20/200 for OS. A temporal superior CCH was evidenced in OS with foveal serous detachment (fig. 1).

We performed laser photocoagulation (the patient refused treatment with PDT) and 3 months later VA improved to 20/100 but foveal serous detachment persisted (fig. 2). Thereafter we decided to begin treatment with oral propanolol daily $(120 \mathrm{mg})$. One month later, VA improved to 20/20 and serous foveal detachment disappeared (fig. 3 ). In addition, his arterial hypertension was under control (125/80 $\mathrm{mm} \mathrm{Hg})$. After 8 months of follow-up, both VA (20/20) and the macular thickness remained stable.

\section{Discussion}

Hemangiomas consist histologically of cavernous and capillary vascular networks. Their physiopathology is still poorly understood; nonetheless, VEGF and basic fibroblast growth factor (bFGF) have been involved in infantile hemangiomas growth [4]. Increased levels of these factors have been detected in cutaneous hemangiomas [5] and VEGFreceptors have been evidenced in proliferative infantile hemangiomas [6].

In addition, it has been shown that hypoxia-induced factors important for postnatal vasculogenesis like hypoxia-inducible factor $1 \alpha(\mathrm{HIF}-1 \alpha)$, HIF-2 $\alpha$ and VEGF are upregulated in children with proliferative infantile hemangiomas, leading to VEGF expression by endothelial cells [4-7].

Propranolol is a nonselective $\beta$-adrenergic receptor blocker, and the adrenergic system is the major regulator of cardiac and vascular function. Capillary endothelial cells express $\beta_{2}$-adrenergic receptors $[7,8]$ which modulate the release of nitric oxide, causing endothelium-dependent vasodilatation. In addition, $\beta$-adrenergic receptor stimulation 
can induce modifications of signal transduction pathways of angiogenic factors such as VEGF or bFGF, enhancing neoangiogenesis in ischemic events [7-9]. Moreover, a study of the use of $\beta$-adrenergic receptor blockers for the treatment of cardiac hypertrophy revealed that carvedilol reversed levels of HIF- $1 \alpha$ and VEGF to baseline values [10].

Therefore propanolol may induce endothelium vasoconstriction, decrease expression of bFGF, HIF- $1 \alpha$ and VEGF through the RAF-mitogen-activated protein kinase pathway $[4,8]$ and inhibit endothelial proliferation. Indeed, $\beta$-blockade induces apoptosis of cultured capillary endothelial cells [11].

Different treatments had been performed for this benign tumor. Laser photocoagulation induces resolution of subretinal fluid, exudative retinal detachment and tumor regression; however, subretinal fluid has a high tendency to recur, and $40 \%$ of patients require additional treatment [12]. Radiotherapy is effective in the majority of cases, but it is associated with significant treatment morbidity. Transpupillary therapy may avoid some of the limitations of laser photocoagulation (especially the failure to induce tumor regression) while avoiding complications of radiotherapy. PDT is the preferred treatment for subfoveal or juxtafoveal $\mathrm{CCH}$. Verteporfin is an important vasoocclusive treatment, and PDT may destroy the tumor without damaging the overlying retina and its vascularization. If the tumor or subretinal fluid persist further, PDT retreatments can be performed, but repeated treatments and over-treatment or overlapping PDT spots may result in delayed choroidal atrophy and fibrosis, limiting the visual outcomes $[2,13]$. Moreover, some authors suggest that it is preferable to avoid treatments within the fovea in order to decrease fibrosis and retinal pigment epithelium (RPE) changes [2].

Long-term visual prognosis for patients with $\mathrm{CCH}$ is guarded secondary to vision loss induced by subretinal fluid, macular edema, foveal distortion, and treatment side effects, like choroidal atrophy, fibrosis and RPE changes.

Nowadays, eyelid and orbital infantile hemangiomas can be treated successfully with oral and topical $\beta$-blockers $[14,15]$. This may entail a new treatment for refractory hemangiomas, foveal hemangiomas, or hemangiomas the treatment of which implies high risk of scarring or RPE changes, like tumors that need PDT retreatment or hemangiomas with thin retinal detachments.

We hypothesized that this treatment would be useful in our patient, who showed no response to laser treatment, refused PDT, and presented poor VA. Although the treatment with $\beta$-blockers has been effective and safe in our patient, we are not able to determine whether laser treatment could have modified the final outcome.

The good visual results after treatment with oral $\beta$-blockers may open a new treatment research line for $\mathrm{CCH}$. Nevertheless, further studies and more cases are required to confirm our observation.

\section{Disclosure Statement}

No authors have any financial/conflicting interests to disclose. 


\begin{tabular}{c|l|l|l}
$\begin{array}{c}\text { Case Reports in } \\
\text { Ophthainology }\end{array}$ & $\begin{array}{l}\text { Case Rep Ophthalmol 2011;2:84-90 } \\
\text { DOI: 10.1159/000325142 }\end{array}$ & $\begin{array}{l}\text { Published online: } \\
\text { February 25, 2011 }\end{array}$ & $\begin{array}{l}\text { O 2011 S. Karger AG, Basel } \\
\text { ISSN 1663-2699 } \\
\text { www.karger.com/cop }\end{array}$ \\
\hline
\end{tabular}
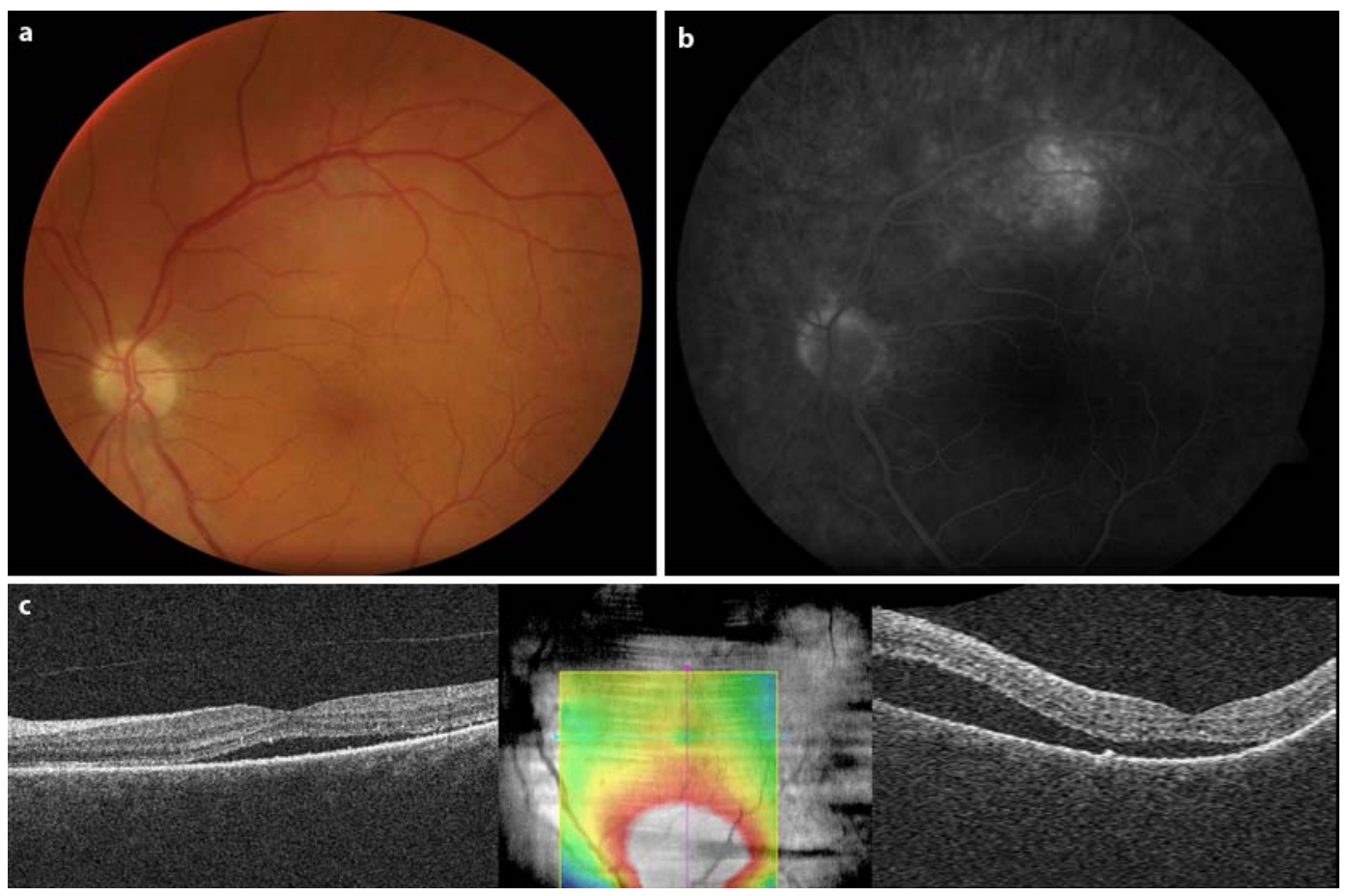

Fig. 1. Baseline appearance of the $\mathrm{CCH}$ : orange choroidal lesion with indistinct margins that blend with the surrounding choroid under the superior temporal arcade (a). Fluorescein angiography showing active leakage (b). Horizontal and vertical optical coherence tomography scans and retinal thickness map, showing serous macular detachment with foveal involvement (c). 


\begin{tabular}{c|l|l|l}
$\begin{array}{c}\text { Case Reports in } \\
\text { Ophthalmology }\end{array}$ & $\begin{array}{l}\text { Case Rep Ophthalmol 2011;2:84-90 } \\
\text { DOI: 10.1159/000325142 }\end{array}$ & $\begin{array}{l}\text { Published online: } \\
\text { February 25, 2011 }\end{array}$ & $\begin{array}{l}\text { O 2011 S. Karger AG, Basel } \\
\text { ISSN 1663-2699 } \\
\text { www.karger.com/cop }\end{array}$ \\
\hline
\end{tabular}
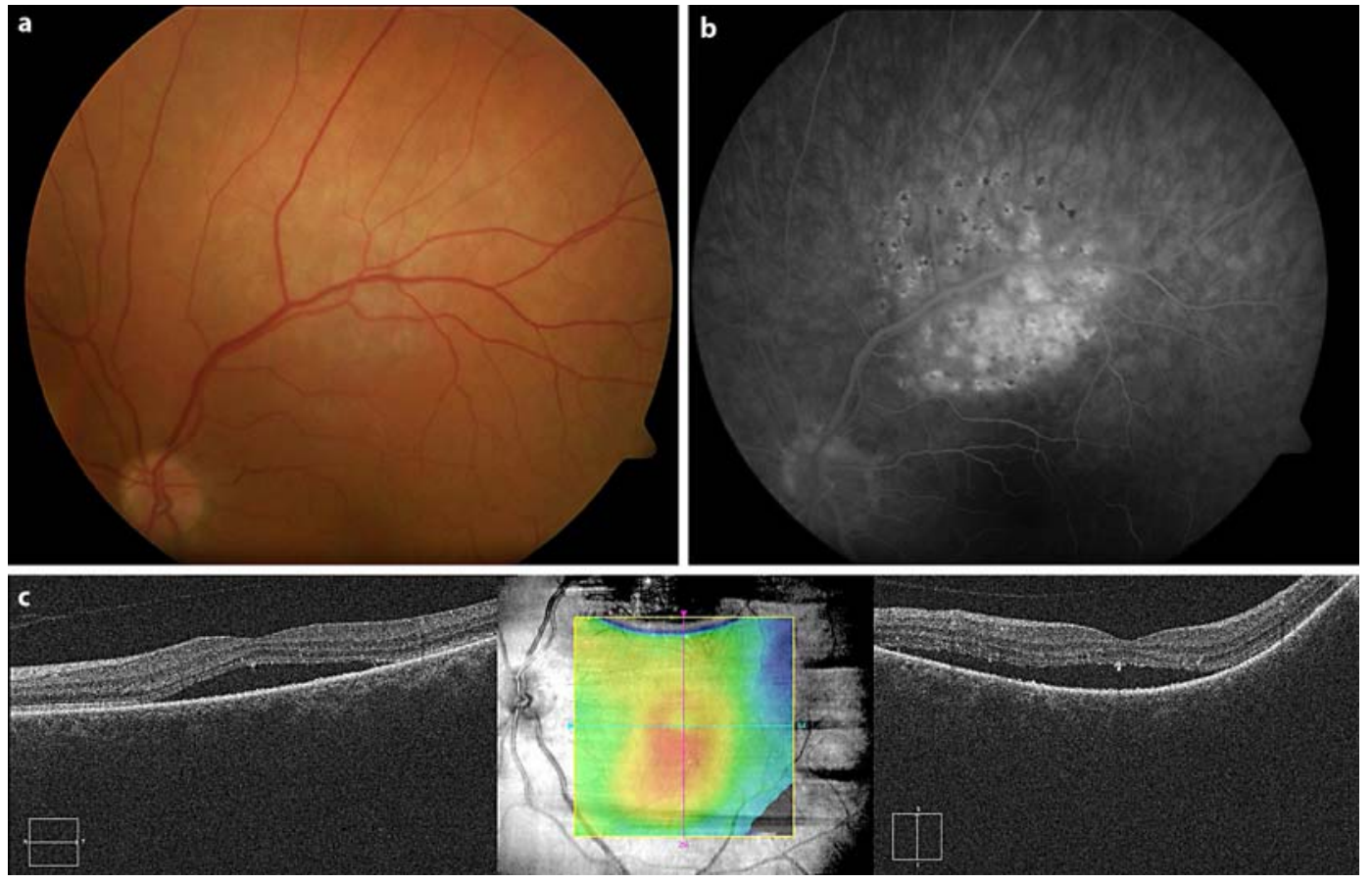

Fig. 2. Fundus appearance 3 months after laser treatment: $\mathrm{CCH}$ remained unchanged with laser scars (a). Fluorescein angiography showing persistent active leakage (b). Horizontal and vertical optical coherence tomography scans and retinal thickness map, showing persistent foveal serous detachment (c). The central macular thickness measured $354 \mu \mathrm{m}$. 


\begin{tabular}{l|l|l|l} 
Case Reports in & $\begin{array}{l}\text { Case Rep Ophthalmol 2011;2:84-90 } \\
\text { DOI: 10.1159/000325142 }\end{array}$ & $\begin{array}{l}\text { Published online: } \\
\text { February 25, 2011 }\end{array}$ & $\begin{array}{l}\text { ○ 2011 S. Karger AG, Basel } \\
\text { ISSN 1663-2699 } \\
\text { www.karger.com/cop }\end{array}$ \\
\hline
\end{tabular}
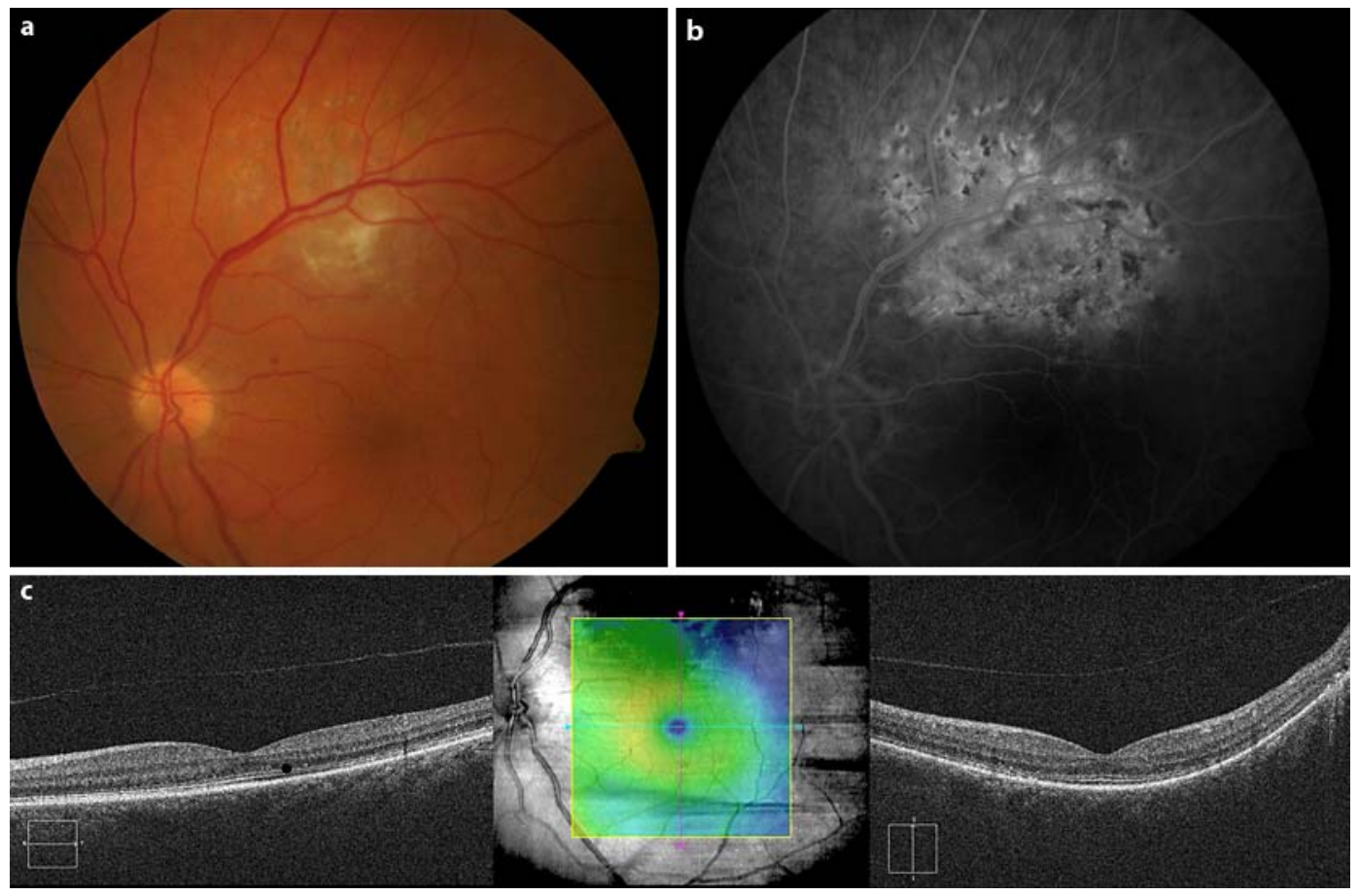

Fig. 3. Fundus appearance after 8 months of treatment with oral propanolol (a). Fluorescein angiography did not evidence active leakage (b). Horizontal and vertical optical coherence tomography scans and retinal thickness map, showing macular re-attachment with restitution of the photoreceptor layer integrity (c). The central macular thickness measured $280 \mu \mathrm{m}$.

\section{References}

1 Shields CL, Honavar SG, Shields JA, Cater J, Demirci H: Circumscribed choroidal haemangioma: clinical manifestations and factors predictive of visual outcome in 200 consecutive cases. Ophthalmology 2001;108:2237-2248.

-2 Tsipursky MS, Golchet PR, Jampol LM: Photodynamic therapy of choroidal hemangioma in Sturge-Weber syndrome, with a review of treatments for diffuse and circumscribed choroidal hemangiomas. Surv Ophthalmol 2011;56:68-85.

$\checkmark 3$ Léauté-Labrèze C, Dumas de la Roque E, Hubiche T, Boralevi F, Thambo JB, Taïeb A: Propranolol for severe hemangiomas of infancy. N Engl J Med 2008;358:2649-2651.

-4 Kleinman ME, Greives MR, Churgin SS, Blechman KM, Chang EI, Ceradini DJ, Tepper OM, Gurtner GC: Hypoxia-induced mediators of stem/progenitor cell trafficking are increased in children with haemangioma. Arterioscler Thromb Vasc Biol 2007;27:2664-2670.

-5 Bielenberg DR, Bucana CD, Sanchez R, Mulliken JB, Folkman J, Fidler IJ: Progressive growth of infantile cutaneous hemangiomas is directly correlated with hyperplasia and angiogenesis of adjacent epidermis and inversely correlated with expression of the endogenous angiogenesis inhibitor, IFN-beta. Int J Oncol 1999;14:401-408.

-6 Frieden IJ, Haggstrom AN, Drolet BA, Mancini AJ, Friedlander SF, Boon L, Chamlin SL, Baselga E, Garzon MC, Nopper AJ, Siegel DH, Mathes EW, Goddard DS, Bischoff J, North PE, Esterly NB: Infantile hemangiomas: current knowledge, future directions. Proceedings of a research workshop on infantile hemangiomas, April 7-9, 2005, Bethesda, Maryland, USA. Pediatr Dermatol 2005;22:383-406.

7 Giatromanolaki A, Arvanitidou V, Hatzimichael A, Simopoulos C, Sivridis E: The HIF-2/VEGF pathway activation in cutaneous capillary hemangiomas. Pathology 2005;37:149-151.

8 D'Angelo G, Lee H, Weiner RI: cAMP-dependent protein kinase inhibits the mitogenic action of vascular endothelial growth factor and fibroblast growth factor in capillary endothelial cells by blocking Raf activation. J Cell Biochem 1997;67:353-366. 
9 Iaccarino G, Ciccarelli M, Sorriento D, Galasso G, Campanile A, Santulli G, Cipolletta E, Cerullo V, Cimini V, Altobelli GG, Piscione F, Priante O, Pastore L, Chiariello M, Salvatore F, Koch WJ, Trimarco B: Ischemic neoangiogenesis enhanced by beta2-adrenergic receptor overexpression: a novel role for the endothelial adrenergic system. Circ Res 2005;97:1182-1189.

10 Shyu KG, Liou JY, Wang BW, Fang WJ, Chang H: Carvedilol prevents cardiac hypertrophy and overexpression of hypoxia-inducible factor- 1 and vascular endothelial growth factor in pressure-overloaded rat heart. J Biomed Sci 2005;12:409-420

11 Sommers Smith SK, Smith DM: Beta blockade induces apoptosis in cultured capillary endothelial cells. In Vitro Cell Dev Biol Anim 2002;38:298-304.

12 Anand R, Augsburger JJ, Shields JA: Circumscribed choroidal hemangiomas. Arch Ophthalmol 1989;107:1338-1342.

13 Jurklies B, Anastassiou G, Ortmans S, Schüler A, Schilling H, Schmidt-Erfurth U, Bornfeld N: Photodynamic therapy using verteporfin in circumscribed choroidal haemangioma. Br J Ophthalmol 2003;87:84-89.

-14 Taban M, Goldberg RA: Propranolol for orbital haemangioma. Ophthalmology 2010;117:195-195.

15 Guo S, Ni N: Topical treatment for capillary haemangioma of the eyelid using beta-blocker solution. Arch Ophthalmol 2010;128:255-256. 